\title{
The Folk-Healing Recipes of the Thasian Monk Gymnasios Lavriotis
}

\author{
By Steven M. Oberhelman*
}

\begin{abstract}
In the spring of 1930, a healing monk on the Greek island of Thasos became the center of international attention. The monk, named Gymnasios Lavriotis, had been trained from childhood as an herbalist and practical folk healer. While serving as a priest in the mountain village of Theologos, Gymnasios offered healing recipes to hundreds of sick people who had travelled from other island villages and even the Greek mainland. His medical recipes (293 in number) have survived through accounts in newspapers of Kavala, Thessaloniki, Epirus, and Athens. Since no study of this fascinating healer exists other than several brief Greek entries, this article serves as an introduction to the life and career of this monk, as well as his healing recipes, materia medica, and therapeutic practices.
\end{abstract}

In the spring of 1930, all of Greece was, as a newspaper reporter phrased it, "shaken like an earthquake" by reports of miraculous healings performed by a monk on the island of Thasos, about 125 miles northeast of Thessaloniki. Writers for newspapers throughout Greece flocked to the mountaintop village of Theologos to see for themselves the activities of this monk, named Gimansios Lavriotis. Some reports branded him a charlatan or quack, while others praised him as a miracle worker and an herbalist of the highest order. But who and what was he? In what follows I offer a brief introduction to his life, a discussion of his materia medica, a review of his medical recipes and recorded therapies, and then conclude with an assessment of his place in traditional Greek medicine. This article is timely for two reasons. First, no English study on the monk exists. The only studies I have been able to find are a journal in the regional journal Thasiaka and the introduction of a 1930 book containing Gymnasios's recipes, both written in Greek (see note 1 below). This article is intended partly to serve as a means to bring the monk to a wider audience. Second, traditional medicine, as well as traditional folk healers like Gymnasios, are currently the subject of extensive scholarly work. With the advent of modern synthetic medicines and the easy access to formal medicine in hitherto unreachable areas of the world, people are turning away from traditional medicine. Younger adults show little interest in the plant concoctions of previous generations, and so as the older generation dies, so too does their knowledge of plant medicine and traditional medicine. Scholars are trying their utmost to preserve the knowledge of local traditional medicine across the globe before its practitioners pass away. Moreover, many of the environments that have been home to medicinal plants are disappearing to the encroachment of civilization, and so scientists are anxious to learn as much as

${ }^{*}$ Professor \& Associate Dean of Undergraduate Programs, Texas A\&M University, USA.

https://doi.org/10.30958/ajh.2-3-3

doi=10.30958/ajh.2-3-3 
they can about the healing properties that these plants contain for the purpose of replicating the properties synthetically.

Gymnasios Lavriotis was born Georgios Tzanetis in 1858 in the small mountain village of Theologos on the island of Thasos. ${ }^{1}$ He pursued botany from an early age, as his mother was a practical nurse/midwife who relied on herbalism. His grandfather was an herbalist who healed local villagers for their stomach ailments, wounds, kidney problems, and rheumatism; he used a large number of medical recipes that he had copied from a manuscript he had read in the library of a monastery on Mount Athos (Primikidi 1930: 15). ${ }^{2}$ Gymnasios told his biographer that as a child he memorized these recipes and observed the healing practices of his mother. At the age of 20, Gymnasios went to England where he secured work as a nurse for a physician-herbalist named Kazis, who, after recognizing Gymnasios's extensive botanical knowledge, taught him anatomy and his own herbalistic practices. For the next several years Gymnasios worked as a nurse in Kazis's clinic before returning home to Greece. In Thessaloniki he served as an assistant to the physician Konstantinidos who furthered Gymnasios's knowledge of herbal medicine.

During World War I, Gymnasios worked as a nurse at the English airbase in the Thasian village of Kazaviti. One day the airplane on which he was flying was shot down and crashed near the Monastery of Hagia Anni at Mount Athos. Gymnasios was healed by the monastery's physician Spiridon, who was also an avid and accomplished botanist. ${ }^{3}$ Gymnasios stayed on and, assuming the name Gymnasios Lavriotis, became a monk at the Monastery of Megisti Lavra on Mount Athos. Gymnasios healed his fellow monks, but soon his reputation became great that he was expelled by his jealous superiors. He went to the Thessalian city of Serrai where for eight months he carried out a healing practice until moving home to Thasos.

Gymnasios settled in the village of Potamia where he became sexton of the local church. Gymnasios resumed healing, but toiled in relative obscurity until in April of 1930 a spectacular healing caused his fame to spread across the island. A seventeen-year old boy was dying. The boy's father pleaded with Gimansios to come and help. After examining the boy, Gymnasios left, returning with handfuls of various plants. He then gave the parents strict instructions on how to make decoctions from the plants and in what dosages

\footnotetext{
${ }^{1}$ The basic source for the life is Primikidi 1930, who offers a discussion (pp. 1-61) based on his personal travels with the monk (see below). Primikidh's account, however, ends in early 1931, seven years before Gymnasios's death. He also has little to say about Gymnasios's early life; for this see Michalopoulos 1992. These two sources are in effect the only studies on Gymnasios other than newspaper accounts published in 1930.

${ }^{2}$ Gymnasios could not remember the name of the monastery.

${ }^{3}$ Many monks at Mount Athos at the time practiced herbalism. Sir Arthur Hill (1937: 197-198) wrote about a plant-collecting expedition he made in 1934 with two other botanists to the Athos peninsula in northern Greece. There they encountered a monk whose knowledge of plants impressed them: he was walking in the fields in his long black robe collecting henbane and liquorice root. He also carried with him a large, black, bulky bag, which, as Sir Hill discovered, contained four carefully wrapped manuscript folio volumes of the first-century A.D. On Medical Substances of Dioscorides which the monk had himself copied out. See Lardos 2012 for twentieth-century monks and their herbal medicine on the island of Cyprus.
} 
the drinks were to be taken. Gymnasios went on to predict that in twenty days a cyst filled with pus would form in the boy's thigh, and so he promised to come back to heal it. Sure enough, a cyst formed twenty days later. Gymnasios lanced and drained the pus, and after cleaning the wound, he placed plants on it and bandaged the thigh. When the boy made a full recovery, the parents went throughout the territory praising the healing powers of the monk. ${ }^{1}$

As a result of this healing, patients began to seek Gymnasios's help in ever increasing numbers. One day the mayor of Theologos appeared at Gymnasios's house and pleaded with the monk to become the village's doctor since their only healer, a practical healer, had died; as incentives, the mayor promised a farm and a position at the church. Gymnasios agreed, since he felt aggrieved that Theologos, his hometown, was without any healer (Chionis 1988). He became priest at the church of Panagouda and settled in a house next to the church. ${ }^{2}$ In a very short time Gymnasios's botanical medical skills became common knowledge not only throughout the island but on the mainland. Within weeks more than 300 sick people had taken up residence in the church courtyard or in the side streets. Every day motorboats, steam ships, and even rowboats brought the sick to Thasos, and the roads to Theologos were clogged with donkeys carrying the invalids. The villages' civil authorities were appalled at the situation and feared for both their own and the sick's health and wellbeing. Since days could transpire before Gymnasios could see a patient, the person would often lay in the village's streets for that whole time in deplorable conditions. The village simply had no infrastructure to handle the crowds: no food, no sanitation services, no housing. The authorities were thoroughly concerned over possible outbreaks of epidemics, diseases, and infections; typhoid fever was especially feared. At first the authorities tried to limit the number of patients entering the village and to provide for those already jammed in the crowded conditions throughout the small town, but the patients kept coming. Finally the authorities in the mainland city of Kavala, the capital of the prefecture that included Thasos, sent the police to arrest the monk for practicing medicine without a university-issued license; the reason was to move the monk to the mainland and, it was hoped, to have the sick follow him (which they did). Gymnasios was taken to Kavala and examined by the prosecuting attorney who released him since the monk had never received money for any of his treatments. Gimansios, however, was expressly warned to cease practicing medicine. By this time newspapers had caught wind of this monk's sensational healing and throughout the months of June and July of 1930 began to report on the events in Theologos. The publicity only resulted in even more people flocking to the island and village to seek a cure. ${ }^{3}$ The authorities

\footnotetext{
${ }^{1}$ When I travelled in 2014 to Thasos, I intervened a man (93 years in age) who had received the same treatment from Gimansios when he was 10 years old and had an abscess in his right side. Gymnasios used a scalpel-like knife (he could not remember the instrument exactly) to lance the wound and drain the pus and then inserted various herbs into the wound.

${ }^{2}$ Because Gymnasios never accepted any money for his services, he earned his livelihood from the 150 chickens he kept on his farm.

${ }^{3}$ Primikidi (1930: 40) writes that he himself arrived on July 8, after weeks of reports filed by other newspapers. Primikidi, the then director of the Kavalan newspaper Tachydromos, filed in
} 
were forced once again to act and so ordered a second arrest of the monk. On 3 August 1930, Gymnasios was seized and transported to the mainland. Wherever the monk was taken, large crowds (often several thousands) of admirers would arrive and harass the gendarmes. The prefect of the Kavala district ordered Gymnasios to be taken to Mount Athos in the hope that he would be placed in seclusion and would soon be forgotten. At Mount Athos Gymnasios was subjected to hardships and mistreatment at the Monastery of Hagia Lavra. The reason was that Gymnasios could not tolerate the conduct of that monastery's priors and sub-priors, and whenever he could, he expressed those opinions openly and freely. After 24 days Gymnasios left Mount Athos at his own request (Primikidi) or, more likely, on the expulsion orders of the abbot (Michalopoulos). Gymnasios was sent to Athens where he was placed in the Attica Dromokaïteio Psychiatric Hospital for evaluation. Why he was subjected to a psychiatric examination is never explained, but doubtlessly some civil and religious authorities bore the monk animosity while a few may have been concerned over the monk's behavior and attitude (constantly refusing to obey directives of a civil court, openly courting arrest, purposely berating his religious superiors). Certainly the far-off location of the hospital, the suburbs of Athens, 450 miles distant from Kavala, was chosen to remove the monk from the public eye in the north. Gymnasios was judged sane and healthy, and after the intervention of the archdiocese of Athens, he was sent on his release to the Monastery of Hagios Meletios in northern Attica. But soon thousands of automobiles clogged the Attica roads leading to the secluded monastery on a daily basis, as people sought a cure from the monk. Just as earlier on the island of Thasos, the Athenian authorities were alarmed at the potential for epidemics and the exacerbation of disease through unsanitary conditions. Finally the National Minister of the Interior, at the urging of the metropolitan bishop of Athens, allowed Gymnasios to return to Thasos, but not before sending the prefect of Kavala a telegram in which he ordered no further prosecution of the monk. On 3 October 1930, Gymnasios left the monastery and after a lengthy trip made it back to Theologos, where he lived until his death in 1938 at the age of $80 .^{1}$

Greece is very rich in vascular plants, over 6,000 of them; many of these are documented as having medicinal properties (Vokoua et al. 1993: 187). Gymnasios possessed a working knowledge of several thousand of them. $\mathrm{He}$ used to walk in the countryside, in the hills, along the roads, through the fields, always looking for plants. After collecting them, he experimented on them to see what healing properties they possessed. ${ }^{2}$ Gymnasios took great pride in

October and November 1980, as a fiftieth-year anniversary, a series of articles in Tachydromos on the monk.

${ }^{1}$ There is hardly any mention of Gymnasios after his final return to Thasos, despite the sensation he had created both in Greece and even across Europe for eight months. The monk evidently lived in relative obscurity, practicing his herbal medicine, attending to his religious duties, and raising chickens.

${ }^{2}$ A parallel is the monk described in note 3 above. See also the discussion in Clark 2011:31-35, for a practical healer on the island of Crete whose experiments of local fauna were well known to his villagers. 
claiming that his knowledge did not come from books but from practical experience. In one newspaper interview, the monk said: "Botanists learn plants from books, but I learned in the hills and in the villages. I know 2,000 plants and their properties of healing." ${ }^{1}$ When a patient consulted Gymnasios, the monk examined him personally and then offered a remedy. A secretary wrote down the recipe, since Gymnasios did not know how to read and write; the recipe was typically brief (two or three sentences) and contained instructions on what plants to use and in what doses. ${ }^{2}$

A collection of 293 recipes has come down to us, thanks to an Athenian journalist who travelled with Gymnasios between his first arrest and his final return to Thasos. This journalist, Ioannou Primikidi, became Gymnasios's closest friend and unofficial biographer. One day, right before Gymnasios was seized by the mainland authorities for a second time, Primikidi asked Gymnasios to tell him his recipes. Primikidi transcribed and published them in a small volume in Athens in 1930 while Gymnasios was living at the monastery of Hagios Meletios. The transcriptions are accurate, as I have compared them with those recipes reported in newspaper articles of the day (Michalopoulos 1992: 282-283).

The recipes are simple, using primarily local plants. Doses, if specified, are often in multiples of 10 or 50 , thus making it easy for memorization. As examples of his recipes, let me offer the two for treating "festering sores in the stomach:"3

\section{Festering Sores in the Stomach}

80. We boil parsley, couch grass, and corn silk. We [drink this decoction] for five or six days. (If bleeding occurs, this should not scare you.) Next we knead the following items: a spoonful of ground black pepper, a spoonful of sugar, a little crushed cinchona, and an egg. We make pills, which we take three times daily. At the same time we take a flat piece of bread and roast it over a fire. We dip it into vinegar and then immediately spread pure tar on top. We bind the bread on the part of the stomach that is causing pain and keep it there for the entire night. We do this for six days. All the while, we also take the pills as described above.

\footnotetext{
${ }^{1}$ Newspaper interview published in Makedonika Nea (Thessaloniki) (July, 1930), 29.

${ }^{2}$ See Chionis 1996: 554-560, for practical healers on Thasos in the years right before Gymnasios; they too had little formal training (only a few were literate), but all used tried and tested plant recipes learned from their parents and grandparents.

${ }^{3}$ All translations are mine and are based on Primikidi's 1930 text. (As only a few copies exist of this small book, I was fortunate to locate a copy in a folklore bookshop in Monasteraki a few years ago.) Many different "collections" of Gymnasios's recipes were subsequently published, with the number of recipes increasing to 369 and then to over 450 . But these additional recipes are spurious. (I would point out that the title of Primikidi's book itself is misleading: the title says "304 recipes", but there are actually 293, since the numbering sequence is in error in several places. Even in 1930, there were many spurious collections of recipes that were falsely ascribed to Gymnasios (Michalopoulos 1992: 282-285); in fact, these spurious collections were what compelled Primikidi to publish his book, with the blessing of Gymnasios (who had hitherto refused to divulge them despite handsome monetary offers).
} 
81. Another method. We take 50 drams of rhubarb, 50 drams of butter, 50 drams of ash tree sap, 50 drams of Chian mastic, 50 drams of cinchona, two eggs, and two spoonfuls of tar. We make a substance from all these things and after we knead, we throw in two spoonfuls of cinnamon oil. We make pills and take four a day, always before eating something.

Or for anemia,

9. We take 100 drams of cinchona, 100 drams of sugar, 50 drams of cinnamon, 100 drams of black pine tree bark, and one dram of quinine. We boil everything in three okas of water. We drink three glasses of this every day.

10. Another method. We boil in a half-oka of wine 100 drams of couch grass, 100 drams of sugar, 100 drams of cinchona, and two handfuls of spleenwort. We drink a glass of this liquid every day.

13. Another method. We take a half-oka of black pine tree [bark], 100 drams of cinchona, 100 drams of sugar, two cypress berries, 100 drams of celery, and 50 drams of cinnamon. We boil all these ingredients and then filter. We drink three small glasses of [the liquid] daily.

14. Another method. We take 50 drams of wormwood, 50 drams of cinnamon, and 50 drams of cinchona. We boil these in two okas of wine and then drink two small wine glasses of this daily.

In some recipes, Gymnasios recommends diet and regimen, in conjunction with plant therapy. ${ }^{1}$ For example, for epilepsy:

92. First of all, a total change in diet is required. Meat is completely forbidden. The patient is to eat only Lenten meals, dairy [products], and a little fish. Also, squeeze hard the patient's upper arm in order to puff up a vein in the middle of the wrist. Prick this vein with a burning-hot needle; a little fluid will come out. Next, after 15 days, remove blood from the scapula with a cupping glass and then give [the patient] the following recipe: We take 100 drams of wormwood, 100 drams of cinchona, and a half-oka of bitter almonds (first blanch and soften the seed coats). All these [ingredients] are to be boiled in a half-oka of water until an oka remains [in the pot]. Filter the liquid. The patient takes three small glasses of this daily. The diet [given above] should be continued for a year, however. Finally, it is necessary for the patient to be girded at the waist with a belt made of the skin of an ass. Also, according to the treatment, he must avoid, as much as possible, getting his extremities wet. Or for heavy whitish foam in one's urine (albuminuria):

\footnotetext{
${ }^{1}$ This multipronged approach to healing is typical of early modern Greek healing texts and in fact stretches back to Hippocrates' On Regimen in the fifth/fourth century BC; see Oberhelman 2013: 286-294, with examples from folk healing texts contemporary with Gymnasios.
} 
133. We take a half-oka of couch grass and four potatoes. We boil these in a proportionate amount of water. We drink a glass of this daily. We also follow a diet of milk, yogurt, potatoes, rice, and leafy vegetables, with no bread allowed.

In Gymnasios's recipes, plants and herbs predominate. I have been able to identify 124 different plants, the most common flora in Table 1. All but three can be found on the island and could be picked easily by Gymnasios as he walked through the countryside collecting his plants; the three outliers could have been purchased at any apothecary.

Table 1. Most Frequent Flora Found in Gymnasios's Medical Recipes

\begin{tabular}{|l|l|l|}
\hline Plant & Occurrences & Found on Thasos? \\
\hline Cinchona & 20 & no \\
\hline Mastic & 17 & yes \\
\hline Garlic & 16 & yes \\
\hline Parsley & 14 & yes \\
\hline Rice & 13 & yes \\
\hline Wheat & 13 & yes \\
\hline Black pine tree & 12 & yes \\
\hline Juniper tree & 11 & yes \\
\hline Mint & 11 & yes \\
\hline Cinnamon & 10 & no \\
\hline Rhubarb & 10 & yes \\
\hline Black cumin & 9 & yes \\
\hline Celery & 9 & yes \\
\hline Couch grass & 9 & yes \\
\hline Incense & 8 & no \\
\hline Spleenwort & 8 & yes \\
\hline Cypress berry & 7 & yes \\
\hline Fig & 7 & yes \\
\hline Ash tree sap & 5 & yes \\
\hline Corn silk & 5 & yes \\
\hline Honeysuckle & 5 & yes \\
\hline Potato & 5 & yes \\
\hline Winter savory & 5 & yes \\
\hline & & \\
\hline
\end{tabular}

There are also many uses of animal substances, oils, and minerals (Table 2): 31 ingredients come from animals, such as dog bones and puppy skulls; oils made from olives, cinnamon, camphor, as well as vinegar and wine; and 49 mineral substances. Gymnasios also used new substances (new in that they were not used in antiquity or through the early modern period of Greece): chocolate, gunpowder, ouzo, and raki.

Table 2. Most Frequent Non-Flora Found in Gymnasios's Medical Recipes

\footnotetext{
${ }^{1}$ For the gradual accumulation of new substances (mostly foreign and from the New World) into Greek practical medicine, see the excellent discussions in Clark 2002 and 2011: 39-45; Papadopoulos 2009, and Touwaide 2007.
} 


\begin{tabular}{|l|l|}
\hline Animal or Mineral Substance, Oils & Occurrences \\
\hline Chicken egg (whole, white, yolk, shell) & 43 \\
\hline Tar & 35 \\
\hline Sugar & 31 \\
\hline Olive Oil & 26 \\
\hline Vinegar & 22 \\
\hline Sulfur & 20 \\
\hline Wax & 19 \\
\hline Wine & 18 \\
\hline Alum & 11 \\
\hline Iron shavings & 10 \\
\hline Cow urine and dung & 9 \\
\hline Indigo & 9 \\
\hline Puppy or dog bones & 8 \\
\hline Camphor & 7 \\
\hline Raki & 6 \\
\hline
\end{tabular}

The heavy use of eggs, sugar, oils, sulfur, tar, wax, and alum may be attributed to Gymnasios's methods of treatment. Although about half of the recipes involve ingestion (drinking a tea or a boiled plant decoction: 114 times), equally important are homemade pills (32) and the external application of ointments (70) and compresses (38). Pills, ointments, and compresses require ingredients eggs, wax, and sugar to serve as bonding agents, softeners, and emulsifiers. Waters and oils were used to make teas and pills and also for drops (for the eyes and ears: 10 times) and for fumigation through steam or vapor (nine times).

An important question is, What diseases did Gymnasios treat? Did he specialize or did he treat every ailment? The following is a breakdown of the diseases and conditions to be found in his the 293 recipes (Table 3). 
Table 3. Breakdown of Medical Conditions Treated by Gymnasios

\begin{tabular}{|l|l|}
\hline Disease or Condition & Occurrences \\
\hline $\begin{array}{l}\text { Gastrointestinal tract (including hemorrhoids, hernias, and } \\
\text { prolapse of anus) }\end{array}$ & 31 \\
\hline Skin diseases, burns, nails & 27 \\
\hline Nervous system, weakness, spasms & 26 \\
\hline Pains and headache & 23 \\
\hline Mouth, gums, teeth, throat, voice & 23 \\
\hline Eye and sight & 21 \\
\hline Blood, veins, anemia, hemorrhages & 19 \\
\hline Sexual diseases & 16 \\
\hline Fevers, inflammations, infections & 16 \\
\hline Urinary tract, liver, spleen & 14 \\
\hline Kidneys, stones & 14 \\
\hline Respiratory tract and system & 12 \\
\hline Bones, joints, and fractures & 10 \\
\hline Wounds, ulcers & 8 \\
\hline Cardiovascular system & 6 \\
\hline ears and hearing & 4 \\
\hline Swellings, dropsy & 4 \\
\hline Gynecology and obstetrics & 3 \\
\hline Toxicology (poisons, bites) & 1 \\
\hline Other ${ }^{1}$ & 15 \\
\hline
\end{tabular}

The most common ailments that Gymnasios treated concern the gastrointestinal tract, the skin, the sensory organs, wounds and cuts, pains, and the nervous system. Healing texts from classical times and the Byzantine period also emphasized these very same diseases (Touwaide 2007: 164-173). ${ }^{2}$ But there are differences too. Gymnasios has only one instance of a bite, while Touwaide's statistics show that about nine percent of recipes deal with toxicology. The difference may lay in the fact that there are few poisonous animals on Thasos (for example, of the seven snake species, only two are poisonous and those are very afraid of humans). Gymnasios also avoids gynecological issues (religious reasons? personal reasons?), but he is unique in how frequently sexual diseases like gonorrhea and syphilis occur. Is it significant that Gymnasios's treatments focused so much on sexual diseases, ocular problems, hematology, and pain (especially rheumatism), compared to Touwaide's statistics for earlier healing texts? Are these patterns local? This is an area for further investigation and would require extensive data analysis.

\footnotetext{
${ }^{1}$ These include both medical and nonmedical matters: hair loss (4), malaria (2), diabetes (2), anorexia (1), counteraction against magical spells (1), seasickness (1), nocturnal emissions (1), obesity (1), preventing disease (1), and gaining a strong memory (1).

${ }^{2}$ I am currently completing a monograph on three early modern Greek healing texts, and my preliminary data show that the most frequently treated conditions are the gastrointestinal tract, skin diseases, wounds and infections, and various pains. See also Clark 2011: 280-287, for ailments treated by her folk healer (died 1979).
} 
A final issue is, How did Gymnasios learn his herbal medicines? As we have seen, his knowledge came from other herbalists, such as family members, botanists with whom he worked, and healers under whom he worked in a quasi-apprentice mode (Chionis 1996: 550-556, Clark 2011: 14). ${ }^{1}$ But from where did those people acquire their knowledge of plants and their medical applications? The answer is traditional medicine, which can be traced back all the way to the classical period, to the fifth century B.C., and as communicated by villagers and family members through the generations (McNamara 20032004). Recent medical anthropologists and ethnographers have studied traditional Greek medicine in various parts of the mainland and the islands; their aim has been to document the medical practices of the older generation of healers before it fades away (Brussell 2004, Hanlidou et al. 2004, Lardos 2006, 2012, Lardos and Heinrich 2013, Malamas and Marselos 1992, Vokoua et al. 1993). ${ }^{2}$ In the columns of Table 4 , I describe sideritis and its use for specific ailments, as recorded by recent scholars who have examined old medical recipe books and as told to them by villagers, monks, and owners of herbal shops and plant stalls in marketplaces. I also place in the far right column the medical uses of the same plant in the great first-century A.D. work, On Medical Substances of the Greek pharmacologist/herbalist Dioscorides (Riddle 1985).

There is a remarkable continuity in the knowledge of medical plants from antiquity down to the turn of this century. How was that knowledge passed down? The answer, I would argue, has been by oral transmission by country dwellers who live around, and work with, plants every day: root-cutters, professional plant collectors, drug-sellers, farmers, and owners of herb gardens. In classical Greece, root-cutters collected plants and herbs that were medically beneficial and then sold them at county fairs. Drug-sellers sold plant recipes to country and city people alike. Both types still exist in Greece today. In Thessaloniki, one can still go to the market and buy medicinal herbs and plants from professional plant harvesters and owners of herb stalls. One can relate one's ailment to the personnel who offer a diagnosis and offer plants with instructions on usage.

\footnotetext{
${ }^{1}$ This sort of transmission is precisely how practical healers had passed along their knowledge for centuries.

${ }^{2}$ This all ties into the World Health Organization's efforts to record traditional medicine across the globe (WHO 2001).

${ }^{3}$ The multiple healing sources that Greek people in nonurban areas still use are documented in Blum and Blum 1965 and 1970.
} 
Table 4. Sideritis in Traditional Greek Healing

\begin{tabular}{|c|c|c|c|c|c|c|c|c|c|}
\hline Taxon & $\begin{array}{l}\text { Common } \\
\text { name }\end{array}$ & $\begin{array}{l}\text { Zagori, } \\
\text { Epirus } \\
\text { (texts and } \\
\text { healers) } \\
\text { (Vokoua } \\
\text { et al. 1993) }\end{array}$ & $\begin{array}{l}\text { Vikos-Aoos, Epirus } \\
\text { (texts) (Malamas and } \\
\text { Marselos 1992) }\end{array}$ & $\begin{array}{l}\text { Vikos-Aoos, } \\
\text { Epirus } \\
\text { (healers) } \\
\text { (Malamas } \\
\text { and Marselos } \\
\text { 1992) }\end{array}$ & $\begin{array}{l}\text { Thessaloniki } \\
\text { (market } \\
\text { healers and } \\
\text { herbal shops) } \\
\text { (Hanilou } \\
\text { et al. 2004) }\end{array}$ & $\begin{array}{l}\text { Thessaly } \\
\text { (folk } \\
\text { healers) } \\
\text { (Brussell } \\
2004 \text { ) }\end{array}$ & $\begin{array}{l}\text { Cyprus } \\
\text { (texts) } \\
\text { (Lardos } \\
2012 \text { ) }\end{array}$ & $\begin{array}{l}\text { Cyprus } \\
\text { (monasteries) } \\
\text { (Lardos } \\
2012 \text { ) }\end{array}$ & Dioscorides \\
\hline sideritis & $\begin{array}{l}\text { ironwort, } \\
\text { mountain } \\
\text { tea }\end{array}$ & $\begin{array}{l}\text { cough (dried } \\
\text { flowers and } \\
\text { leaves } \\
\text { boiled in } \\
\text { water; one } \\
\text { cup of the } \\
\text { tea drunk } \\
4-5 \text { times a } \\
\text { day), sore } \\
\text { throat }\end{array}$ & 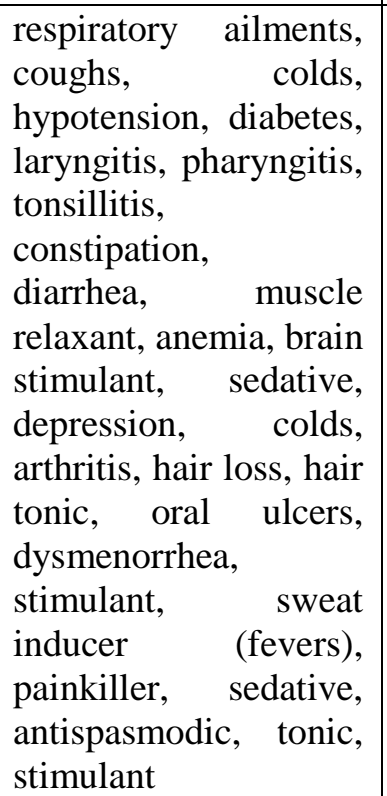 & $\begin{array}{l}\text { respiratory } \\
\text { ailments }\end{array}$ & $\begin{array}{l}\text { dyspepsia, } \\
\text { anemia, } \\
\text { influenza, } \\
\text { colds, } \\
\text { sedative, } \\
\text { diuretic, } \\
\text { anti-fever, } \\
\text { stimulant }\end{array}$ & & & & $\begin{array}{l}\text { The leaves } \\
\text { when applied } \\
\text { close open } \\
\text { wounds and } \\
\text { reduce } \\
\text { inflammation. }\end{array}$ \\
\hline
\end{tabular}


Table 5. Stinging Nettle in Traditional Greek Healing

\begin{tabular}{|c|c|c|c|c|c|c|c|c|c|}
\hline Taxon & $\begin{array}{l}\text { Common } \\
\text { name }\end{array}$ & $\begin{array}{l}\text { Zagori, } \\
\text { Epirus } \\
\text { (texts and } \\
\text { healers) } \\
\text { (Vokoua } \\
\text { et al. } \\
\text { 1993) }\end{array}$ & $\begin{array}{l}\text { Vikos-Aoos, } \\
\text { Epirus (texts) } \\
\text { (Malamas and } \\
\text { Marselos } \\
\text { 1992) }\end{array}$ & $\begin{array}{l}\text { Vikos-Aoos, } \\
\text { Epirus } \\
\text { (healers) } \\
\text { (Malamas and } \\
\text { Marselos } \\
\text { 1992) }\end{array}$ & $\begin{array}{l}\text { Thessaloniki (market } \\
\text { healers and herbal shops) } \\
\text { (Hanilou et al. 2004) }\end{array}$ & $\begin{array}{l}\text { Thessaly } \\
\text { (folk } \\
\text { healers) } \\
\text { (Brussell } \\
\text { 2004) }\end{array}$ & $\begin{array}{l}\text { Cyprus } \\
\text { (texts) } \\
\text { (Lardos } \\
2012 \text { ) }\end{array}$ & $\begin{array}{l}\text { Cyprus } \\
\text { (monasteries) } \\
(\text { Lardos 2012) }\end{array}$ & Dioscorides \\
\hline $\begin{array}{l}\text { urtica } \\
\text { dioica }\end{array}$ & $\begin{array}{l}\text { stinging } \\
\text { nettle }\end{array}$ & $\begin{array}{l}\text { Hyper- } \\
\text { tension } \\
\text { (plant } \\
\text { boiled in } \\
\text { water; a } \\
\text { wineglass } \\
\text { of the } \\
\text { liquid } \\
\text { drunk } \\
\text { twice } \\
\text { daily), } \\
\text { diuretic }\end{array}$ & $\begin{array}{l}\text { bronchitis, } \\
\text { hemostatic, } \\
\text { hypertension, } \\
\text { diarrhea, } \\
\text { dysentery, } \\
\text { chronic } \\
\text { hepatitis, } \\
\text { diuretic, } \\
\text { wounds, } \\
\text { swellings, } \\
\text { paralysis }\end{array}$ & $\begin{array}{l}\text { skin diseases, } \\
\text { hypertension, } \\
\text { hemorrhoids, } \\
\text { urinary } \\
\text { disorders, } \\
\text { tonic, } \\
\text { stimulant, } \\
\text { rheumatism, } \\
\text { arthritis }\end{array}$ & $\begin{array}{l}\text { blood circulation } \\
\text { stimulant, hemorrhoids, } \\
\text { hypertension, diabetes, } \\
\text { constipation, gallstones, } \\
\text { liver disorders, anemia, } \\
\text { hemostatic, headache, } \\
\text { arthritis, rheumatism, } \\
\text { dandruff, eczema, hair } \\
\text { loss, dysmenorrhea, } \\
\text { kidney stones, } \\
\text { aphrodisiac, purification } \\
\text { blood stimulant }\end{array}$ & $\begin{array}{l}\text { Tea from } \\
\text { the leaves } \\
\text { is drunk } \\
\text { to treat } \\
\text { kidney } \\
\text { stones. }\end{array}$ & $\begin{array}{l}\text { Gastro- } \\
\text { intestinal } \\
\text { and liver, } \\
\text { musculo- } \\
\text { skeletal, } \\
\text { oral } \\
\text { cavity, } \\
\text { respiratory } \\
\text { tract }\end{array}$ & $\begin{array}{l}\text { cardiovascular } \\
\text { and blood, } \\
\text { gastro- } \\
\text { intestinal and } \\
\text { liver, } \\
\text { musculo- } \\
\text { skeletal, } \\
\text { respiratory } \\
\text { tract, } \\
\text { urogenital }\end{array}$ & $\begin{array}{l}\text { Cures dog bites } \\
\text { gangrene, } \\
\text { malignancies, cancers } \\
\text { ulcers, dislocations } \\
\text { tumors, inflammation } \\
\text { of the parotid gland } \\
\text { and abscesses. Helps } \\
\text { the spleen and stops } \\
\text { nosebleeds. Induces } \\
\text { menstrual flow and } \\
\text { restores a prolapsed } \\
\text { womb. Helps asthma } \\
\text { pleurisy, and } \\
\text { pneumonia, and clears } \\
\text { the chest. Soften } \\
\text { bowels and induces } \\
\text { urine. }\end{array}$ \\
\hline
\end{tabular}


The point I am trying to make is that knowledge of plant medicine has always been possessed by people whom we would consider illiterate and unlearned. Although hardly any of them could read and write, they knew the properties of the medical plants growing on their farms and near their villages. When someone in their family fell ill, they knew exactly what plant to pick and how to make it into a medicine-for example, how to make a tea with it, and then how many cups of tea one should drink each day and for how many days. If they suffered a severe wound, they knew what oils could be extracted from which plants and how to fashion a poultice with those oils. They taught their children these cures, and then those children taught their children.

A final question: How have farmers and villagers, even those still alive today, known that certain plants are so effective at healing particular ailments and afflictions? Through observation and experimentation. It is popularly commented that every Greek knows that sideritis or ironwort, today known as Greek mountain tea, is, if drunk, a wonderful way to stay healthy and that it can overcome a number of ailments. Our medical sources in the Table 4 use it accordingly: recipe books and herbal shop and marketplace healers, as well as monks and village herbalists, use it for coughs, sore throats, respiratory ailments, tonsillitis, anemia, influenza and colds, and to help with stomach and bladder problems. Dioscorides, all the way back in the first century AD, wrote that the plants' leaves healed wounds and reduced inflammation.

But does sideritis work? Country folk have said yes for centuries, but a modern skeptic may laugh and say, Not likely. But modern scientists, who are now the effectiveness of the pharmacology of traditional healers at counteracting disease, have shown (and here I refer to the first column of Table 4) that sideritis possesses a strong anti-inflammatory, gastro-protective, antibacterial, and anti-oxidant properties (González-Burgos et al. 2011, Tadič et al. 2012, and Villar et al. 1986). What science has uncovered are the triggers for how this plant counteracts disease in the human body; farmers and practical healers knew only that the plant worked through their empirical observations. Likewise with respect to the stinging nettle (Table 5): the fresh leaves contain chemical compounds that have a demonstrable anesthetic and analgesic effect and can counteract inflammation. Because the plant's root increases the volume of urine and reduces residual urine, it is effective in treating prostatitis. The stinging nettle has also been shown to be a viral inhibitor of HIV-1, HIV-2, and influenza (Chrubasik et al. 2007, Koch 2001, Konrad et al. 2000, Lopatkin et al. 2006, Popa et al. 2005, Safarinejad 2005, Schneider and Rubben 2004, Schulze-Tanzil et al. 2002, and Wilt et al. 2000). Thus, the Physicians' Desk Reference for Herbal Medicines recommends it for the prostate, urinary tract problems, kidney stones, diarrhea, dysentery, bowel bleeding, blood circulation, osteoarthritis, and inflammatory diseases of the lower urinary tract (Physicians' Desk Reference for Herbal Medicines 2000: 729-33).

Is any of this new? No, as Dioscorides and all the written and oral sources in Table 5 had recognized these very same healing abilities of the stinging nettle. Modern medicine has made significant strides, and technology has made a long healthy life possible for many. But one wonders whether we have truly 
improved upon a healing monk walking through the fields of the island of

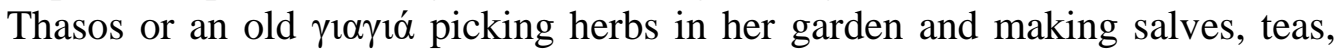
and homemade pills for her family and neighbors.

\section{References}

Blum R, Blum E (1965) Health and Healing in Rural Greece: A Study of Three Communities. Stanford: Stanford University Press.

Blum R, Blum E (1970) The Dangerous Hour: The Lore of Crisis and Mystery in Rural Greece. London: Chatto and Windus.

Brussell DE (2004) Medicinal plants of Mt. Pelion, Greece. Economic Botany 58 (Supplement): S174-S202.

Chionis K (1988) The doctors of Thasos and Kavala during the period 1860-1930. Thasiaka 5: 82-92. [In Greek].

Chonis K (1996) Practical medicine on Thasos during the Tourkokratia. Thasiaka 9: 549-573. [In Greek].

Chrubasik JE, Roufogalis BD, Wagner H, Chrubasik S (2007) A comprehensive review on the stinging nettle effect and efficacy profiles: part II: urticae radix. Phytomedicine 14: 568-579.

Clark PA (2002) Landscape, memories, and medicine: traditional healing in Amari, Crete. Journal of Modern Greek Studies 20: 339-65.

Clark PA (2011) A Cretan Healer's Handbook in the Byzantine Tradition: Text, Translation and Commentary. London: Ashgate Publishing.

González-Burgos E, Carretero ME, Gómez-Serranillos MP (2011) Sideritis spp.: uses, chemical composition and pharmacological activities: a review. Journal of Ethnopharmacology 135: 209-225.

Hanilou E, Karousa R, Kleftoyanni V, Kokkini S (2004) The herbal market of Thessaloniki (North Greece) and its relation to the ethnobotanical tradition. Journal of Ethnopharmacology 91: 281-299.

Hill AW (1937) Preface. In: Turrill WB. A contribution to the botany of Athos Peninsula. Bulletin of Miscellaneous Information (Royal Gardens, Kew) 4: 197273.

Koch E (2001) Extracts from fruits of saw palmetto (sabal serrulata) and roots of stinging nettle (urtica dioica): viable alternatives in the medical treatment of benign prostatic hyperplasia and associated lower urinary tracts symptoms. Planta Medica 67: 489-500.

Konrad L, Muller HH, Lenz C, Laubinger H, Aumuller G, Lichius JJ (2000) Antiproliferative effect on human prostate cancer cells by a stinging nettle root (urtica dioica) extract. Planta Medica 66: 44-47.

Lardos A (2006) The botanical materia medica of the iatrosophion: a collection of prescriptions from a monastery in Cyprus. Journal of Ethnopharmacology 104: $387-406$.

Lardos A (2012) Historical Iatrosophia Texts and Modern Plant Usage in Monasteries on Cyprus. $\mathrm{PhD}$ thesis, University of London.

Lardos A, Heinrich M (2013) Continuity and change in medicinal plant use: the example of monasteries on Cyprus and historical iatrosophia texts. Journal of Ethnopharmacology 150: 202-214.

Lopatkin N A, Sivkov AV, Medvedev AA, Walter K, Schlefke S, Avdeichuk Iul, Golubev GV, Mel'nik KP, Elenberger NA, Engelman U (2006) Combined 
extract of sabal palm and nettle in the treatment of patients with lower urinary tract symptoms in double-blind, placebo-controlled trial. Urologiia 2(12): 1419.

Malamas M, Marselos M (1992) The tradition of medical plants in Zagori, Epirus (Northwest Greece). Journal of Ethnopharmacology 31: 197-203.

McNamara L (2003-2004) Conjurers, purifiers, vagabonds, and quacks? The clinical roles of the folk and Hippocratic healers of classical Greece. Iris: Journal of the Classical Association of Victoria 16-17: 2-25.

Michalopoulos N (1992) The father Gymnasios Lavriotis. Thasiaka 7: 263-292. [In Greek].

Oberhelman SM (2013) Dreams, dreambooks and post-Byzantine practical healing manuals (iatrosophia). In: Oberhelman SM (ed.) Dreams, Healing and Medicine in Greece: From Antiquity to the Present. London: Ashgate Publishing, 269-94.

Papadopoulos C (2009) Post-Byzantine medical manuscripts: new insights into the Greek medical tradition, its intellectual and practical interconnections, and our understanding of Greek culture. Journal of Modern Greek Studies 27: 107-130.

Physicians' Desk Reference for Herbal Medicine (2000). $4^{\text {th }}$ edn. Montvale, NJ: Medical Economics Company.

Popa G, Hagele-Kaddour H, Walther C (2005) Efficacy of a combined sabal-urtica preparation in the symptomatic treatment of benign prostatic hyperplasia: results of a placebo-controlled double-blind study. MMW Fortschritte der Medizin 147 (Supplement)3: 103-108.

Primikidi I (1930) The history of Gymnasios Lavriotis, with his 304 authentic recipes. Athens: Papadogianne Publishers. [In Greek].

Riddle J (1985) Dioscorides on Pharmacy and Medicine. Austin: University of Texas Press.

Safarinejad MR (2005) Urtica dioica for treatment of benign prostatic hyperplasia: a prospective, randomized, double-blind, placebo-controlled, crossover study. Journal of Herbal Pharmacotherapy 5: 1-11.

Schneider T, Rubben H (2004) Stinging nettle root extract (bazoton-uno) in long term treatment of benign prostatic syndrome (BPS): results of a randomized, doubleblind, placebo-controlled multicenter study after 12 months. Der Urologe A. 43: 302-306.

Schulze-Tanzil G de SP, Behnke B, Klingelhoefer S, Scheid A, Shakibaei M (2002) Effects of the antirheumatic remedy hox alpha -a new stinging nettle leaf extract- on matrix metalloproteinases in human chondrocytes in vitro. Histology and Histopathology 17: 477-485.

Tadić V, Jeremic I, Dobric S, Isakovic A, Markovic I, Trajkovic V, Bojovic D, Arsic I (2012) Anti-inflammatory, gastroprotective, and cytotoxic effects of sideritis scardica extract. Planta Medica 78: 415.

Touwaide A (2007) Byzantine hospital manuals (iatrosophia) as a source for the study of therapeutics. In: Bowers B (ed.) The Medieval Hospital and Medical Practice. London: Ashgate Publishing, 147-173.

Villar A, Recio MC, Ríos JL, Zafra-Polo MC (1986) Antimicrobial activity of essential oils from sideritis species. Die Pharmazie 41: 298-299.

Vokoua D, Katradi K, Kokkini S (1993) Ethnobotanical survey of Zagori (Epirus, Greece), a renowned centre of folk medicine in the past. Journal of Ethnopharmacology 39: 187-196.

Wilt TJ, Ishani A, Rutks I, MacDonald R (2000) Phytotherapy for benign prostatic hyperplasia. Public Health Nutrition 3(4A): 459-472. 
Vol. 2, No. 3 Oberhelman: The Folk-Healing Recipes of the Thasian Monk...

WHO (2001) Legal status of traditional medicine and complementary/alternative medicine: a worldwide review. Geneva: World Health Organization. 